a common understanding that academic values are the bedrock upon which managerial values are brought into play.

Perhaps most enabling of all, we find the entrepreneurial university to be a place that diversifies income to the point where its financial portfolio is not heavily dependent upon the whims of politicians and bureaucrats who occupy the seats of state policy, nor upon business firms and their "commercial" influence, nor even upon student tuition as main support. Funds flow not only from such well-identified sources but also, crucially, from a host of public agencies (other than the coresupport ministry or department) and alumni and other private donors who provide moral and political support as well as direct year-to-year funding and accumulation of endowment. Effective stewardship comes to depend not on the state or on "the market," but on university self-guidance and self-determination. The entrepreneurial university does indeed provide a new basis for achievement.

My qualitative case studies of exemplars of change offer a strong lesson for future research. Concepts induced from exemplary practices are strengthened by the reassurance of solid facts-documented actions taken in defined contexts. More good case studies that lay bare those facts will be needed to further illuminate the character of entrepreneurial universities emerging and evolving at a rapid rate, internationally, in the early years of the 2ist century.

\section{New Typologies for Crossborder Higher Education}

\section{JANE KNIGHT}

Jane Knight is adjunct professor at the Ontario Institute for Studies in Education, University of Toronto. She is currently a visiting scholar at ITAM in Mexico and adviser to GX4 UEALC Project of CENEVAL. E-mail: janeknight@sympatico.ca.

G iven the increase in demand for higher education, there are new providers, new delivery methods, and types of programs. These new providers include media companies such as Pearson (U.K.), Thomson (Canada); multinational companies such as Apollo (USA), Raffles (Singapore), and Aptech (India); corporate universities such as those run by Motorola and Toyota, and networks of universities, professional associations, and organizations. Generally, these new commercial providers are mainly occupied with teaching/training or offering services and do not focus on research per se. They can complement, cooperate, compete, or simply coexist with the traditional public and private higher education institutions with the traditional mandate of teaching, research, and outreach.

It is not just for-profit companies that are becoming increasingly interested in commercial crossborder initiatives.
Conventional higher education institutions, both private and public, are also seeking opportunities for commercial delivery of education programs in other countries. The majority of these are bona fide institutions that comply with domestic and foreign regulations (where they exist), but also on the increase are rogue or low-quality providers who are not recognized by bona fide accreditation/licensing bodies. Another worrisome development is the mushrooming of "degree mills" operating around the world. Many of these ventures are nothing more than web-based companies that are selling certificates based on "life experiences" and are not delivering education programs at all.

The expansion in number and type of entities that are providing education courses and programs across borders is causing some confusion. This also applies to the increasing diversity in delivery modes. The general state of flux may indicate progress and innovation, but it also begs for some kind of classification system or typology to make sense of the new context of crossborder education.

\section{The word "provider" is used as a generic term to include all types of higher education institutions as well as companies and networks involved in crossborder education.}

\section{Classifying Crossborder Providers}

A typology for six different types of crossborder providers is presented. A key factor is that the type of provider is purposely separated from the mode of mobility. To date, much of the discussion about program and provider mobility has linked the type of provider with a certain mode of delivery. This approach is one reason for the state of confusion. A generic classification system for crossborder providers has thus been proposed and separate classification systems are used for the different modes of program and provider mobility.

This typology is a work in progress. The word "provider" is used as a generic term to include all types of higher education institutions as well as companies and networks involved in crossborder education. Four key factors are used to describe each category of provider and to distinguish one group from another: whether the provider is public, private, or religious; whether it is nonprofit or for-profit; whether it is recognized by a bona fide national licensing or accrediting body; and whether it is part of the national "home" higher education system.

The first category includes "recognized higher education institutions" and can be public, private, or religious institutions - either nonprofit or profit-oriented. The institutions are usually part of the home national education system and are recognized by a domestic bona fide licensing or accrediting body, and are often referred to as the traditional type of higher education institution.

"Nonrecognized higher education insitutions" comprise the second group and are usually private in nature and for-profit in 
purpose. This category includes institutions that provide a course of study but are not recognized by a national bona fide evaluation body in the home or foreign country. The level of quality can differ greatly, but if these institutions are of low quality they are often referred to as rogue providers and usually seek accreditation from bodies that sell an accreditation label. Degree mills are different from rogue providers in that they usually do not provide a course of study; they focus on selling an award.

"Commercial company higher education institutions" make up the third category and are primarily profit-oriented companies that can be privately owned or publicly traded. The institutions or programs established by these companies are not usually part of a 'home' national education system and, may or may not, be recognized by bona fide licensing or accreditation bodies. A variety of national companies and international conglomerates can be included in this group. These companies are often referred to as a type of "new provider" and over 50 of them are included in the Observatory on Borderless Higher Education Global Education Index of companies that are publicly traded and deliver education programs and services across borders.

"Corporate higher education institutions" are the fourth group that is characterized by being part of a major international conglomerate and that exists outside of a national education system. These institutions provide education and training for their employees. They are not usually recognized by a licensing or accrediting body but will often collaborate with traditional higher education institutions in order to access degree-awarding powers through a partnership.

\section{Virtual higher education institutions may or may not be part of a nationally based higher education and therefore may or may not be recognized by a bona fide licensing or accreditation body.}

The fifth category is more general and includes different types of "networks and affiliations." These types of partnerships can be any combination of public or private institutions and companies and can involve complex arrangements in terms of academic, financial, legal, and accreditation issues. The profit motive is often the catalyst that brings the different players together to work crossborder, even though some of the partners may be nonprofit in the home context. These innovative networks and affiliations are also referred to as new providers.

"Virtual higher education institutions" constitute the sixth group. They rely primarily on delivering education by distance (usually on-line) and in some cases, they may provide face-toface support for students through their own study centers or in cooperation with local partners. Virtual higher education institutions may or may not be part of a nationally based higher education and therefore may or may not be recognized by a bona fide licensing or accreditation body. It is very difficult for receiving countries to monitor or regulate international virtual higher education institutions due to distance-delivery modalities.

\section{Key Issues}

One of the central issues is who recognizes and gives the provider the power to award the qualifications in the "home or sending country" or in the "host or receiving country." However, many new providers are not part of, or are not recognized by, a home (or foreign) national education system, and this raises key issues. Another challenge focuses on the terms "public, private and religious," as they are interpreted and used in different ways among countries. The emergence of new trade regulations applying to education services means that commercial crossborder providers are usually considered to be private by the host or receiving country regardless of their status at home. This adds yet another complicating dimension to the task. Furthermore, the definition of profit and nonprofit varies among receiving nations. Consequently, many countries are overhauling their national regulatory systems for crossborder education, for purposes of both liberalization and protection, and this merits close scrutiny.

\section{Many countries are overhauling their national regulatory systems for crossborder education, for purposes of both liberalization and protec- tion, and this merits close scrutiny.}

\section{Programs on the Move}

Crossborder mobility of programs can be described as the "movement of individual education/training courses and programs across national borders through face-to-face, distance, or a combination of these modes." Credits toward a qualification can be awarded by the sending foreign country provider, or by an affiliated domestic partner, or jointly. Franchising, twinning, double/joint degrees, articulation, and validation models, plus virtual delivery are the more popular methods of crossborder program mobility. The use of virtual delivery is one example of why it is important to separate the type of provider from the mode of mobility as it is clearly not just virtual higher education institutions who are using distance delivery for crossborder program delivery.

\section{Providers on the Move}

Not only courses and programs are moving across borders, so are the providers. Crossborder mobility of a provider can be described as "the physical or virtual movement of an education provider across a national border to establish a presence to provide education or training programs and/or services to students and other clients." The difference between program and provider mobility is one of scope and volume in terms of pro- 
grams or services offered and the local presence (and investment) by the foreign provider. Credits and qualifications are awarded by the foreign provider (through foreign, local, or selfaccreditation methods) or by an affiliated domestic partner or jointly. The key question remains who monitors and recognizes the "legitimacy" and "recognition" of the qualification for future study and employment purposes. The forms of crossborder provider mobility include branch campuses, merger with or acquisition of domestic providers, independent institutions, study and support centers, virtual delivery, plus other types of innovative affiliations. A distinguishing feature between program and provider mobility is that with provider mobility the learner is not necessarily located in a different country than the awarding institution as is the case with program mobility; and this raises other issues and challenges.

\section{Academic Corruption: The Continuing Challenge}

\section{Philip G. Altbach}

Philip G. Altbach is Monan professor of higher education and director of the Center for International Higher Education at Boston College.

$\mathbf{T}^{\mathrm{f}}$ the spate of news reports about corruption in higher edu1 cation indicates the scope of the problem, the world is seeing a dramatic increase in the phenomenon. Not only is corruption undermining the core values of higher education in some parts of the world, it is creating problems of credibility as societies link universities with unsavory practices. After all, higher education's bedrock mission consists of the pursuit of knowledge and truth. Universities worldwide have long claimed special privileges of autonomy, academic freedom, and support by society precisely because of their devotion to the public good and their reputations for probity. They have long enjoyed high social prestige precisely for these commitments. If universities lose their standing in society as special institutions, they will suffer unparalleled damage.

\section{Stories of Corruption}

Here is a sampling of current press reports on academic corruption. These stories provide a sense of the scope and variety of the problem worldwide.

Russia is introducing a national entrance test for university admissions, in considerable part because of perceived corruption in the traditional entrance system. Russian families pay about $\$ 300$ million annually in bribes to ensure acceptance to universities, and another $\$ 700$ million once students are enrolled. A former deputy prime minister put the amount spent on academic bribes at between $\$ 2$ and $\$ 5$ billion a year. Family and political connections account for further corruption in the entry process. The test, it is hoped, will eliminate subjectivity in admissions, allowing meritocratic decisions and also better access for applicants from outside the major cities. The point here is that corruption is seen as so endemic to the system that a major reform had to be implemented in an effort to curb it.

The admissions process involves a lot of corruption because of the coveted nature of access to higher education, especially to the most prestigious universities. With its long history of competitive and highly regarded national examinations for admission to many of its universities, China recently suffered an admissions scandal covered in the national media. University officials demanded a payment of \$12,000 from a student whose test score qualified him for admission to a prestigious university. One critic noted, "Over the past few years, we have been trying to marketize higher education and turn it into an industry...but whenever money is involved in anything, there will be problems." The press reported that this case is "just the tip of the iceberg."

\section{The admissions process involves a lot of corrup- tion because of the coveted nature of access to higher education, especially to the most presti- gious universities.}

The University of Port Harcourt, in southern Nigeria, recently revoked the degrees of 7,254 of its graduates in a crackdown on academic fraud. The head of the university charged students stripped of their degrees with either cheating on examinations or falsifying their academic records, in cases going back to I966. He characterized Nigerian universities as rife with corruption, with many students being admitted with false secondary school certificates. A report by the Exams Ethics Project, a nongovernmental organization, noted that, "Academic fraud and corruption is a big business in Nigeria."

In South Korea, the government demanded that three private universities fire 68 faculty members and administrators, on charges of embezzlement, mismanagement of funds, and bribery. Investigators found that one school diverted $\$ 4.9$ million to personal use and illegally redirected another $\$ 4.6$ million.

\section{Why Now?}

The current focus on corruption in higher education indicates the prevalence of the problem-although the phenomenon is by no means unprecedented in history. While we have no way of knowing if academic corruption is in fact more widespread than in earlier times, it is certainly attracting more attention. One can pose several hypotheses as to why there seems to be more corruption.

The greater scrutiny of academic institutions relates to higher education's high profile for providing social mobility. A successful career requires an academic degree, even if obtained fraudulently or from a "degree mill." As a result, academe attracts more attention, and more criticism, from the mass 